\title{
Political Science of Modern Kazakhstan - Notices to Development of Kazakhstan Political Thinking
}

\author{
Peter Juza ${ }^{1}$
}

\begin{abstract}
„....in this situation allow me to remind the words of Claude LéviStraus: ,... if the 21st century does not become the century of social sciences, it won't be existing at all". Regarding the potential power and world-view of these sciences, e.g. regarding their possible connection with politics, this thesis is very true..." (Šmajs, 2014)
\end{abstract}

The picture of political process as a form of a specific kind of market relations belongs to one of the theoretical issues defined by J. Schumpeter in 1942 in his work "Capitalism, Socialism and Democracy". Thus, politics is a part of economy, where - similarly to the market rules - the competition principles are being used. This was clearly defined also by A. Downs: ,... finally, the market exchange is being realised by exchange of the specific policy for votes... " (Downs, 1957, p. 27-28)

Political science and political thinking have deep historical roots in modern Kazakhstan. Within the half of the last millennium, their sources were the works of Arabic-language philosophy in particular, based on both antique values and traditional nomadic Kazakhs' world view. Its characteristics were the specific concept of a state, state social structure and from the European point of view different relation between man (individual) and society. As the young chairman of the Royal Court of Justice in Bordeaux, Charles de Secondat Monetsquie, wrote: ,.... since I am in Europe, dear Radi, I saw many forms of government: not like in Asia, where equal policy rules are in force... " (Montesquieu, 2009, p. 106)

Folk traditions have represented, represent and apparently will further represent the specific model of power relations legitimization, which have been formed during the time of the Kazakh khan rise. ${ }^{2}$ They were characterized by electiveness of sovereigns - khans, acceptance of the political elite coming from Genghis Khan descendants only, dividing the nation and state in three inseparable parts and rather influential position of judicial power.

1 doc. Mgr. Peter Juza, PhD., CSc., Department of political science and european studies, Faculty of Social Sciences, University Ss. Cyril and Methodius in Trnava, Bučianska 4/A, 91701 Trnava, Slovak republic, e-mail: peter.juza@ucm.sk

2 The settlement originated in 1465 during the disintegration of the Golden Horde on the area of today's Kazakhstan and some neighbouring states. Under the pressure of the Russian imperium (governance of Ekaterina II.), his original form has been abolished in 1847. 
An exceptional contribution to the research of social and political relations of the Middle Asia has been done by the Kazakh etnographer and scholar, Shoqan Shynghysuly Walikhanov $(1835-1865)^{3}$. In his analysis the topics as society division, social and economic situation, public administration methods, the tax system and foreign relations all were emphasized. But his prior topics were "ambitions of the political groups leaders and local sovereigns... " (СМАГУЛОВ, 2001, p. 17) with examples in Eastern Turkhestan and Middle Asia.

In this short historical discussion also Kazakh social philosopher, Abai Kunanbaev (1845-1904), should be mentioned. He helped to infiltrate a part of the Russian and European culture among Kazakhs. He was critical towards the steppe relations, but did not appeal to change „old“ connections.

He said that it is ,,....necessary to build the contemporarysystem while accepting traditions, thousand years old values and ethical norms... "(СМАГУЛОВ, 2001, p. 17) Abai defended national specifications of the judicial system, including the judges life-long appointment within social authorities. For him the future was education and rebirth of national self-confidence. From a certain point of view and using the idea of J. Rawls, the touch of specific steppe justice can be seen in the Abai's concept as some analogy to the constitutional democracy: ,.....we can follow Kant and start with the political concept of reasonably fair constitutional democracy... " (Rawls, 2013, p. 41)

As a certain base for the contemporary Kazakh social sciences, the specific status belongs to works and person of the „main“ Eurasian concept constructor, Lev Nikolayevich Gumilyov.

It is generally known that the term of Eurasia is creating many controversies, emotions, discussions, discrepancies and questions. What is going on? Small Eurasia includes Russia, Turkey and Kazakhstan. According to the majority of experts, big Eurasia is a supercontinent of Europe and Asia. And in this configuration Russia has the longest Eurasian history. ${ }^{4}$ It is based exactly on L.N. Gumilyov's concept, who postulated the syntheses of ethnic Russians and Mongolians in the Great Steppe. Finally, in one of his deciding works he says: „....Eurasia is the biggest continent...consisting of Europe and Asia... “ (Juza, 2014, pp. 89-91)

It is important to remember also that L.N. Gumilyov is the author of the specific ethnogenese theory, where the connection of natural and social sciences has been used. In his texts he is stressing the category of so called ethnos, which is hard to identify with the category of nation within the West European point of view. 3 His complete works in 5 bands can be downloaded under: http://www.razym.ru/ naukaobraz/istoriya/146400-valihanov-sobranie-sochineniy-v-pyati-tomah-t-3-5.html. 4 M.F. Dostojevskij told in 1881 clearly: ,....in Europe we are Tartars, in Asia Europeans...“ 
Why? Because ethnos - at least in the pre-industrial times - was an imprint of certain geographical facts concerning life, profile was forming and survival instruments gaining. Thus, ethnogenese is a process, where superethnos gets through all phases of its evolution from the moment of its origin.

The founders of the modern Eurasian concept, the Russian linguist Nikolai Sergeyevich Trubetzkoy and the historian George V. Vernadsky, aimed their works at different questions within Russia (closer perception) and later within Eurasia (wider perception). In Trubetzkoy's Eurasian concept, the Slavic idea is excluded - not only as a traditional moment of the Russian foreign policy (Slavic messianism), but also as the deciding factor of the Russian world view. Slavism is acknowledged only because of language, but the future of Russia belongs to Eurasia, because, as he says, the future belongs to the Russian-Turan cultural type particularly.

This refusal by Trubetzkoy of the Slavic idea was caused by the negative attitude to Europeanism, which - as for him - meant (and today de facto means) the colonization of Russia and Russian areas of influence. (Grigorova, 2015)

Political science is one of the youngest among the social sciences in Kazakhstan. One of the considerable moments of its forming was in 1991, when the Section and later the Department of Political Science was established at Kazakh State University of Al Farabi in Almaty. This step was followed by the creation of Institute of Philosophy and Political Science of the National Science Academy and the Kazakh Institute for Strategic Research belonging to the Kazakhstan Presidential Office. Then the Institute of Kazakhstan Development was established. From the beginning these places fulfilled the basic tasks of the scientific and pedagogical education in the terms of ,new Kazakh political science“".

The founders of Kazakh political science were well-known Kazakhstan scholars: T. T. Mustafin, A. N. Nysanbaev, A. B. Solovyev, A.V. Kuznetsov, L.A. Baydeldinov, Ž.U. Ibrashev, A.S. Balgimbajev, K.U. Biekenov, S.Z. Normatov, U.T. Kasenov, N.E. Masanov and many more. (ЧЕБОТАРЕВ, 2009, pp. 52-53) To formally close the national process of political science setting of its own, the 1st Congress of Political Scientists was held in 2001 and the Kazakh Political Sciences Association was established.

One of the particularities of the new Kazakh political science forming was and still is the moment of analytical works occurrences, marked by both, quantity and quality. For quantity, a big number of analytical structures was typical, whereby the quality manifested itself in a form of influential ideas within social consciousness and process of submitting essential decisions.

The Kazakh experts perceive the contemporary science as a specific form 
of intellectual investment into the society and state development. As for them and from the quality and quantity of scientific results and innovations point of view, the scientific benefit is defined by both political and economic risks. That is the reason why the fundamentals of research must be defined and scientific independence must be guaranteed by the state.

Quoting experts, not only Kazakh's own school of political science has been formed, but also - as a result of the political science evolution - the adequate external (social-political, economic) and internal (functioning professional political scientists society) conditions have been set as well.

The ethical dimension is to be reminded here. If the state (or another subject) is financially supporting any structure helping to influence the public opinion, it is not clear if the overall freedom to publish the information without censorship is guaranteed. The research of American Roland. H. Chilcot, "Theories of Comparative Politics: The Search for a Paradigm Reconsidered", confirm that it is not the case in the U.S. and every day experience in Kazakhstan shows very similar results. (РОНАЛЬД, 2001)

A second point, refers to bureaucrats within the political science field in Kazakhstan as a result of Michels'applicable ,iron law of oligarchy“: though the "scientific elite“ is being formed, it is supporting conservatism and scientific security i.e. the social scientist mission changes into the professional life filled by bureaucracy, formalism and conformism harmonizing with official doctrines. (Griffin, 1991) By this way, the balance between necessary scientific objectivity and prevailing personal ambitions to stay in a service for power structures, is being lost. Similar to Slovakia? Perhaps.

Above all, the actual problems are connected with a certain kind of atomization of the Kazakh political scientist's field. It is followed by the weak coordination of scientific research at all. Further phenomenon to be mastered is the necessity to extend the publishing work in order to get results of the university researches - if there are any - to the readers and into the public. This is vital since the publication of the strategic document Strategy Kazakhstan - 20505, requires experts to explain to the public how the country will be developed and how its future will be.

Strategy Kazakhstan - 2050 underlines the importance of the present times in Kazakhstan within both the globalization processes and the project of the Eurasian economic union, offering big possibilities to Kazakhstan and the region if the economic union survives.

Kazakh political scientists are stressing the big importance and historical

5 Full transcription of the document „Strategy Kazakhstan - 2050“ under http://www. adilet.gov.kz/kaz2050 
significance of the document, but consider essential to increase the role of discussion platforms concerning the political development of the country and society.

The document Strategy Kazakhstan - 2050 is evidence that the local political elites are able to react quickly and goal-directed towards the new challenges, which are deeper than e.g. fact of the Soviet Union disintegration.

On the congress the experts agreed upon the fact that the „Kazakh model of development " is a project that works in reality. Therefore it seems to be one of the new tasks for Kazakh political scientists to evaluate its results and problem aspects within the policy analyses.

One fact is being stressed in the Kazakh texts and discussions: while studying the political processes it is necessary to accept public opinion as well. The Kazakh society - and this is the fact - lives over an interesting moment of its historical development (and this is to be examined also by the Slovak political science): the previous paradigms are still not exhausted and the new ones did not become dominant yet.

In the last time there can be heard Kazakh experts opinions that within the whole 20th and at the beginning of 21st century Europe lost its fight to be an influential subject in the global competition and thus economic development is turning to Asia. Therefore it is to be assumed that the future of Kazakhstan, is in accepting its geopolitical position, while Europe will try to reverse its loosing position. The external factors will be significant; without studying these factors the Kazakh political science will be moving slowly forward.

Existing geopolitical movements and forming of the new world power centers outlines give a „historical“ chance to Kazakhstan, very similar to that one used by the country in 1991 - non-violent disintegration of the Soviet Union. Within the Kazakh experts discussion on political issues, some particular role plays the price and value of country independence - currently in the context with signing the documents concerning Kazakhstan joining the Eurasian economic union (,Eurasianism“ practically).

Of course that within the internal discussions also simple question is always put: is the project of the European Union (from Kazakhstan point of view) reasonable? According to the local experts, the European choice means borderless and for civilization dangerous individualism, characterized only by priority of personal over common. Simply said, to be a man as I want to be, as my selfish ego wants me to be, disregarding the historical background, religious norms, ethical limits created in hundreds and thousands of years.

According to Kazakh experts circles accepted and spread opinion, the European civilization, except the ambition of self-destruction, does not have any unified 
or at least universal ideological base. Finally, fascism of the last milleniums was born in Europe and under the flag of ,European values “.

As for the local experts, the Eurasian idea is not built on the European categorical imperatives „for" and ,against".

This idea is characterized by mistrust towards the modernisation and civil activity, even though the real Eurasians do have nothing against them. But because of this, a high level of paternalism and specific attitude to the election process can be seen in Kazakhstan.

Eurasianism is based on the experience of ,older people" that is in the direct contrast to everything unknown (alternative political and religious movements, absolute freedom, minorities...). Nowadays Eurasian ideological dilemma is simpler and thus, as for the Kazakh experts, Eurasianism is able to respond to the civilisation challenges more reasonably than Europeanism: ,, within a longterm perspective there is no other alternative for Kazakhstan than the Eurasian integration... "(ЧЕБОТАРЕВ, 2015, p. 405)

There exists intense points within Kazakhian political science, of interesting ideas and handled topics. The main goal is to develop the Kazakh political science in a modern way to be able to further react on challenges - even if this science has been developed idiosyncratic. An exaggerated unity of opinions and attitudes is fortunately missing. As Aristoteles said: ,....but it seems that the pursuit of too big unity of community is not the best... if it is necessary to favour the bigger self-sufficiency, the smaller unity must be favoured as well.... "(Aristoteles,2004, p. 31)

This modernization movement is important not only for science, but also for the social practice of Kazakhstan. Objectively, it is ready for theoretical clarifying of its current and historical moments, of the question where the country occurs and how its direction should be within the final forming of its statehood.

At the end, with some aspects and contemporary political science in Kazakhstan it is correct to note that it has some problems especially in the areas of modern subject education and scientific research.

The Kazakh political science is being developed not only as a scientific discipline, but also as the base for practical research. Its methodology and practical instruments are being improved not only thanks to the active attitude of the local research-expert community, but also thanks to the cooperation with the foreign universities and workplaces of repute, such as in Slovakia. 


\section{REFERENCES}

ARISTOTELÉS (2004) Politika II. OIKYOMEN: Praha, 2004 DOWNS, A. (1957) An Economic Theory of Democracy, N.Y.: Harper

GRIFFIN K. (1991) The Social Science, Academic Freedom and Professional Standards in the United States. Queen's Querterly, 98 (4), p. XX-XX

GRIGOROVA, D. (2015) N. Trubetskoy, G. Vernaddsky: The Ukraianian Issue Eurasian Point of View. Научный исторический журнал "Менгі ел” 01, Astana 2015, pp. 33-35.

JUZA, P. (20114) Sydykov, E.B.: Lev GUMILEV: Encyclopedia. Slovak Journal of Political Sciences, 14 (1). pp. 89-91.

MONTESQUIEU Ch. (2006) Perzské listy. SSS: Bratislava.

RAWLS, J. (2013) Právo národov. Kalligram, Bratislava.

Strategy Kazakhstan - 2050 (2014) Ministry of Justice of the Republic of Kazakhstan [Online] 17 $7^{\text {th }}$ January http://www.adilet.gov.kz/kaz2050 [accessed: $22^{\text {th }}$ October 2015]

ŠMAJS, J. (2014) K problému vědeckosti spoločenských věd. Britské listy. [Online] 20 ${ }^{\text {th }}$ January. Available from http://www.blisty.cz/art/71816.html [accessed: $22^{\text {th }}$ October 2015]

РОНАЛЬД Х.ЧИЛКОТ (2001) Теории сравнительной политологии. В поисках парадигмы,- Москва: Изд. «Весь мир», pp. 64-65.

СМАГУЛОВ, Е.М. (2001) Основы политологии. Фолиант: Астана.

ЧЕБОТАРЕВ А. Е. (2009) Актуальные вопросы развития политической науки в Казахстане, Центр актуальных исследований «Альтернатива», Алматы. pp.52-53.

ЧЕБОТАРЕВ А. Е. (2015) Политическая мысль суверенного. Казахстана,: Астана. 